This item was submitted to Loughborough's Research Repository by the author.

Items in Figshare are protected by copyright, with all rights reserved, unless otherwise indicated.

\title{
Transitions to adulthood among young entrepreneurs in the informal mobile telephony sector in Accra, Ghana
}

PLEASE CITE THE PUBLISHED VERSION

https://doi.org/10.1016/j.geoforum.2017.08.008

PUBLISHER

(C) Elsevier

VERSION

AM (Accepted Manuscript)

\section{PUBLISHER STATEMENT}

This paper was accepted for publication in the journal Geoforum and the definitive published version is available at https://doi.org/10.1016/j.geoforum.2017.08.008.

\section{LICENCE}

CC BY-NC-ND 4.0

\section{REPOSITORY RECORD}

Afutu-Kotey, Robert L., Katherine V. Gough, and Paul W.K. Yankson. 2019. "Transitions to Adulthood Among Young Entrepreneurs in the Informal Mobile Telephony Sector in Accra, Ghana”. figshare.

https://hdl.handle.net/2134/26428. 


\title{
Transitions to adulthood among young entrepreneurs in the informal mobile telephony sector in Accra, Ghana
}

Robert L. Afutu-Kotey, School of Continuing and Distance Education, University of Ghana. Corresponding author: rlakotey@gmail.com

Katherine V. Gough, Department of Geography, Loughborough University: K.V.Gough@lboro.ac.uk

Paul W. K. Yankson, Department of Geography \& Resource Development, University of Ghana, Legon: kojokummm@hotmail.com

\begin{abstract}
The rapid expansion of the mobile telephony sector in African countries has been accompanied by the establishment of a wide range of informal support businesses, mostly run by young people. Little is known, however, about the lived experiences of young entrepreneurs working in this rapidly changing, technologically driven sector. Drawing on qualitative research conducted in Accra, this paper explores young people's experiences of running informal businesses within the mobile telephony sector, including the sale of mobile phones and accessories, repair and technical support services, and the sale of airtime and mobile money services. Fateful and critical moments relating to personal and family events, as well as social networks and structural factors, are shown to mediate young entrepreneurs' chances of success in this new 'niche' economic subsector. Despite the challenges they face, the paper shows how many of these young people have been able to achieve financial independence, afford rental accommodation, provide support for family members, and establish and sustain households. The mobile telephony sector is thus shown to be offering young people the opportunity to carve out a living, facilitate transitions into adulthood, and even enable some to move up the social ladder. By highlighting the agency of this group of young people, and for some their success in achieving the status of adulthood through their hard work and ingenuity, this study offers an important counter balance to images of young people in sub-Saharan Africa as being 'stuck' or in 'waithood'
\end{abstract}




\section{Introduction}

Improvements in African countries’ economic performance in recent decades have not been matched by better opportunities for young people to obtain formal sector employment (Aryeetey \& Baah-Boateng, 2013; Anyidoho, 2013). This has adversely affected their well-being in cities across Africa. Challenges regarding employment and achieving the status of adulthood among young people in many cities in the global South are well documented (Langevang, 2008; Christiansen et al. 2006; Sommers, 2010; Gough et al. 2016). The unemployment situation which propels young people into various forms of informal entrepreneurial activities, and the challenges they face attaining adulthood, are not exclusively a global South phenomenon but are also reported for both the USA and Europe (Bell \& Blanchflower, 2011). A notable difference, however, is that in the global South the number of young people who become unemployed or establish informal businesses after completing school is much greater than in the global North (Jeffrey \& Dyson, 2013). This challenging situation is compounded by the increasing number of young people acquiring formal education in the midst of an unstable economic landscape.

The challenges faced by young people in the global South, particularly in sub-Saharan Africa, have been highlighted by numerous scholars. Christiansen et al. (2006) described the contemporary African youth as a generation born into social environments in which possibilities of earning decent lives are negligible, with many finding themselves stuck in positions of inadequacy having few life chances and bleak prospects. Many young people in an urban African context have been shown to experience highly insecure employment, with this insecurity closely linked to manifestations of insecurity in other aspects of their lives, such as housing and education (Gough et al. 2016). Youth in Africa have thus been depicted as ‘stuck' between childhood and adulthood (Sommers, 2012), a situation also designated as 'waithood', which essentially depicts a transitory period experienced by young people anticipating adulthood (Honwana, 2014). During this period of waithood, young people may engage in various activities ranging from street vending, cross-border trade, and involvement in gangs and other criminal activities (Jeffery \& Dyson, 2013).

Despite these depictions of African youth, some young people have assumed a degree of agency in their lives through their engagement in entrepreneurial and other informal activities, which offers them employment avenues and improvements in social mobility. A sector which has experienced increasing youth entrepreneurial activities in Africa over the past two decades is the 
rapidly expanding mobile telephony sector. In Ghana, for instance, according to the National Communications Authority, the subscriber base to the various mobile telephony networks increased from over 1.5 million in 2004 to about 30 million in 2015. This growth has been accompanied by an increasing number of different types of informal support businesses mostly run by young people. Some of these businesses include sale of mobile phones and accessories, repair and technical support services and the sale of airtime and mobile money services. Very little is known, however, about the lived experiences of young people in this rapidly changing technologically driven sector.

While there has been some fascinating research on the use of mobile phones by young people in sub-Saharan Africa (Porter et al. 2012, 2015; Hampshire et al. 2015), few studies have been conducted on young people engaged in informal businesses in the mobile telephony sector (see though Afutu-Kotey, 2016; Afutu-Kotey et al., 2017). This paper aims to fill this gap by exploring young people's experiences of running a range of informal businesses within the mobile telephony sector, demonstrating how personal and family events, in addition to social networks and structural factors, influence the chances of success among young people in the mobile telephony sector in Accra.

The paper begins by outlining the debates and conceptualisation of youth transitions into adulthood and the link with entrepreneurship, followed by the methodological and analytical approach to the study. A reconstructed biography of three of the young people interviewed in Accra is then presented, followed by a discussion of the critical events shaping young people's transitions to adulthood within the broader context of social space and time. The specific influence of business engagement in the mobile telephony sector on the transitions of young people to adulthood is then discussed, highlighting their successes and the challenges they face. The final section concludes the paper drawing out the finding that the mobile telephony sector is offering some young people the opportunity to become financially independent and transition into adulthood.

\section{Conceptualising youth transitions into adulthood and entrepreneurship}

The concept 'youth' is defined sociologically as the transitory period between childhood and adulthood, and the roles, rights and responsibilities that go with it. Early discourse on youth transitions drew on psychological theories, which perceived youthfulness as a distinct stage and a linear progression in the life course (Erikson, 1950; Inhelder \& Piaget, 1958). Subsequently, 
the inadequacy of considering transitions in terms of a linear progression have been widely discussed in the literature (Furlong \& Cartmel, 2007; Worth, 2009; Wyn \& Dwyer, 1999). In both the global North and South, changes in education and labour market relations have extended youth transitions and made them more complex than the early discussions suggest (Jeffrey \& McDowell, 2004; Valentine, 2003). Contemporary youth transition theories have exposed the fallacy of distinct stages of the life course by addressing new imperatives of a flexible labour market, such as: multiple jobs instead of one career; diverse family dynamics including lower marital rates; and the expansion and prolonged nature of involvement in the education sector (Worth, 2009). Young people's transitions to adulthood have been described as 'waithood' in a section of the literature, as young people stagnate between childhood and adulthood (Hanwana, 2014), while others have described transitions among young people as 'emerging adulthood' (Arnett, 2007).

Beck’s (1992) concept of individualization has received attention in youth transitions discourse, despite the concept being criticised for placing the blame for failing to attain one's 'choice biography' on the individual, without paying much attention to structural barriers that often impede the opportunity to follow-up desired choices (Skelton, 2002; Worth, 2009). This has led to calls for a shift in focus from perceiving young people as actors to include their relationships, and also from addressing them from perspectives of agency to structural concerns (Ansell, 2014). Giddens (1991) made a useful contribution to individualisation debates by arguing that transitions in reflexive modernity are experienced through 'fateful moments' where a person's ontological security is threatened by having to make significant choices about the future. Influenced by Giddens' 'fateful moments', Thomson et al., (2002) conceptualised the concept of 'critical moments', as a way of understanding the key events of transition for young people. As they argue, "the key transitions that might be seen as aspects of adulthood do not occur at the same time or in the same order; their occurrences are not highly correlated, and many of them are reversible” (Johnson-Hanks et al., 2002, p. 869). Young people, therefore, cross the fluid boundaries between time and space specific notions of childhood, youth and adulthood, making transitions a convoluted process.

Social capital theory has also received considerable attention in some aspects of the transitions literature, with Worth (2009) identifying social capital as perhaps having the strongest influence on contemporary transitions debates. Studies examining social capital and young people have 
recognized that young people do not only receive capital from their parents and other relations, but also serve as a source of capital within their own peer groups (Helve \& Bynner, 2007; Worth, 2009). In many of these studies, social capital has been utilised in exploring issues such as social exclusion, where disadvantaged young people's life choices are limited by the economic, cultural and social resources available to them (Arnot et al., 2011). Additionally, social capital theory has been used with other theories of agency and identity, balancing individual choice and structural constraints (Holland et al., 2007).

In a Ghanaian context, there has been limited empirical research on young people's transitions, although the few existing works give credence to the complex and unpredictable nature of youth transitions to adulthood. Commenting on the transition potential of young people in the city of Accra, Langevang (2008, p. 2,039) argued that “achieving respectable adulthoods in present-day Accra is a convoluted journey involving the careful management of social relationships.” Young people do not only move into and out of adulthood, but have to carefully manage these processes by assuming different roles and responsibilities. The complex and unpredictable nature of youth transitions is often attributed to difficult economic circumstances, albeit the role of education and training should not be understated (Clark, 1999; Bennell, 2007; Furlong \& Cartmel, 2007). As in much of sub-Saharan Africa, the inability of the Ghanaian economy to offer formal sector employment to young people has long been identified as contributing to delays in their transitions to adulthood (Clark, 1999; Bennell, 2000, 2007).

In the midst of the difficult transitions confronting young people, entrepreneurship is seen as an alternative means for income generation and moving up the social ladder. Entrepreneurship has been shown to enable young people to become integrated into the labour market, contribute to their economic independence, and to help combat poverty (Schoof, 2006; Gough et al., 2016; Gough \& Langevang, 2016). In a global South context, much of this entrepreneurship takes place within the informal economy, which can be defined as "economic activities that occur outside of formal institutional boundaries but which remain within informal institutional boundaries for large segments of society” (Webb et al., 2013, p. 1). This includes a range of self-employed persons who mainly work in unregistered small entities (Chen, 2012).

There has been little systematic research on entrepreneurship among young people operating in the informal economy in sub-Saharan Africa and the significance of entrepreneurship in the lives 
of the young entrepreneurs (though see Gough \& Langevang, 2016 for exceptions). This paper aims to contribute to addressing this knowledge gap by focussing on self-employed young people working within the mobile telephony sector, who may occasionally employ one or possibly two additional employees. The concepts ‘youth’ and ‘young people’ are used interchangeably to refer to the 15-35 year group defined as youth by the National Youth Policy of Ghana (Government of Ghana/Ministry of Youth and Sports, 2010). Youth is approached through a life course perspective in order to gain a deeper understanding of the lived experiences of young people with a specific focus on the rights, roles and responsibilities that they assume. Young people who successfully assume these roles and responsibilities are classified as having attained the status of adulthood.

\section{Methodological approach}

The study adopted a qualitative research strategy involving several field methods (mapping exercise, life trajectory interviews, and biographical interviews) to collect primary data over the period December 2010 to January 2013. Data collection commenced with a mapping exercise to identify places with a concentration of mobile telephony businesses in Accra, resulting in the selection of five localities: Kwame Nkrumah Circle, Madina Zongo Junction, Kaneshie and Tema Lorry Stations, and the Legon-Madina road (see Figure 1). While Kwame Nkrumah Circle and Madina Zongo Junction were selected as they constitute clusters for different mobile telephony businesses in Accra, other locations were chosen due to concentration of specific kinds of businesses in these spaces (Afutu-Kotey, 2016). For instance, Kaneshie lorry station is unique as it has concentration of mobile phone battery recharging businesses and Tema Lorry Station houses mobile phone accessories businesses that are conducted on push-trucks. 
Figure 1: Map of the Greater Accra Metropolitan Area showing study localities

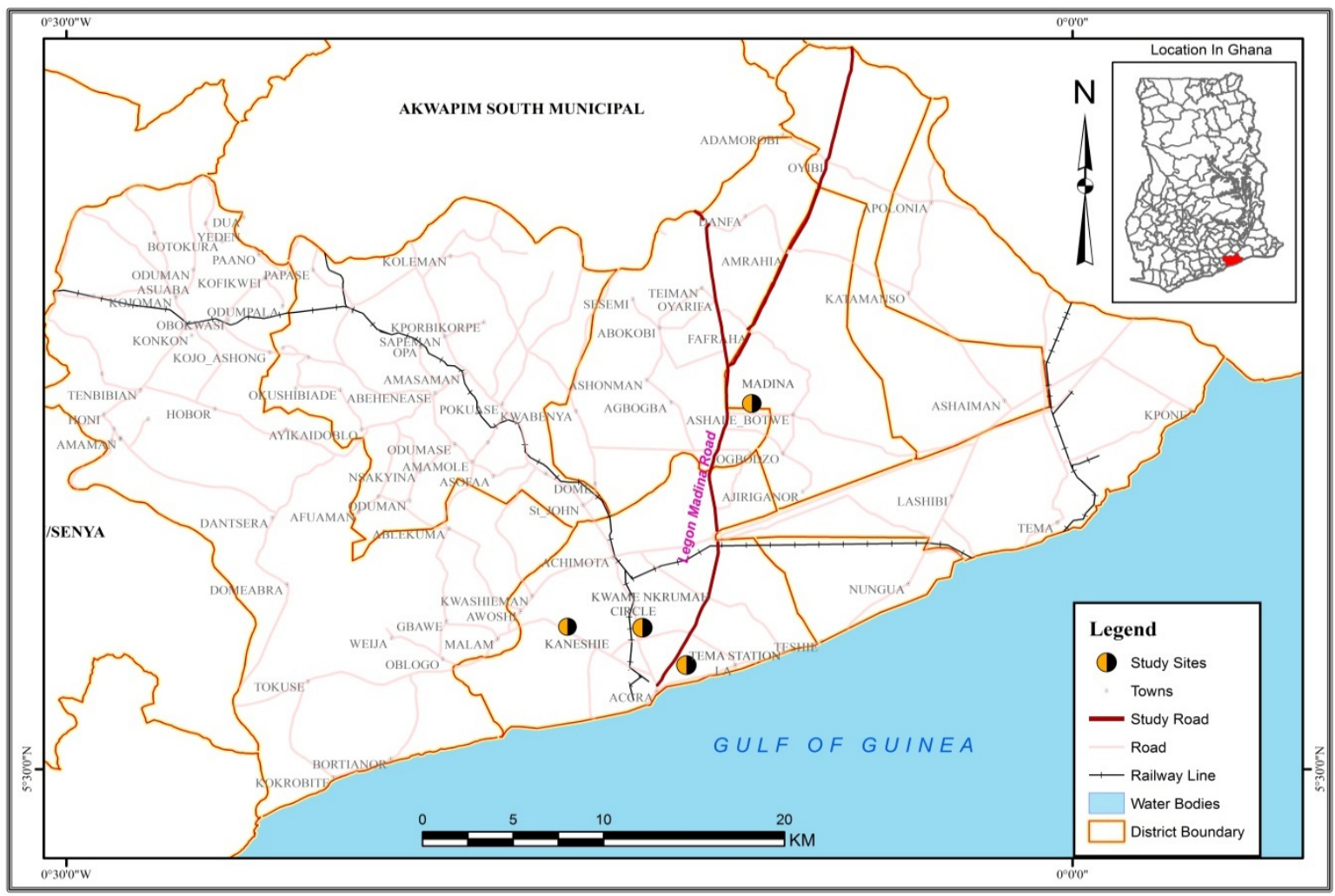

Source: RSGIS Lab, University of Ghana

Following the mapping exercise, 15 young people were purposively selected for the life trajectory interviews, which involved conducting interviews lasting on average 45 minutes with each one on a quarterly basis over three years. At the time of selection, eight of the young people were already operating businesses within the mobile telephony sector, while the remaining seven were partaking in a six-month training course on mobile telephony repairs run by an NGO. The life trajectory interviews monitored temporal changes in the business activities and life courses of the young people. Attention was particularly focussed on specific transition markers in their life courses and the extent to which engagement in mobile telephony businesses has contributed to shaping their lives over time.

In addition, biographical interviews were conducted with 25 young people operating mobile telephony businesses within the study localities, selected to cover a range of business types, both genders, and varied experience. These interviews focussed on the lived experiences of the young people before and after entering the mobile telephony sector; they lasted approximately 50-70 minutes and were conducted at the business premises of the respondents. All of the interviews 
conducted were audio recorded with the consent of the respondents and subsequently transcribed verbatim. Pseudonyms are used here to protect the anonymity of the respondents.

Data from the life trajectory and biographical interviews were analysed using Giddens’ construct of 'fateful moment' and the concept of 'critical moment' by Thomson et al., (2002). As Giddens (1991, p.214) proposed in his discussion of the relationship between self and social structure in late modern society, individuals embark on a "reflexive project of the self" within which they experience 'fateful moments'. Fateful moments are "times when events come together in such a way that an individual stands at a crossroad in their existence or where a person learns of information with fateful consequences” (Giddens, 1991, p. 113). Fateful moments constitute transition points with significant effects, not just for the future of the individual but also their self-identity. Influenced by Giddens' (1991) construct of 'fateful moment', Thomson et al., (2002) proposed the concept of 'critical moment' to constitute an episode set in a particular space and time in the narratives of individuals that is either considered by the researcher or the individual to be of particular biographical significance in the life course. Such events have fundamental meaning in the sense that they define who the individual was previously and who they have become.

In analysing the biographical and life trajectory data, transcripts from the interviews were read numerous times and important experiences in the lives of respondents identified. Particular attention was paid to life course stages or experiences such as childhood, schooling, starting a business, marriage, and housing. This approach helped develop a chronology of life experiences, as well as identifying critical periods and factors shaping young people's experiences. From the narratives, individual biographies were reconstructed and the factors that have shaped the biographies were identified, including the influence of business.

\section{Reconstructed biographies of three young people in the mobile telephony sector}

This section presents reconstructed biographies of three young people selected to represent both the diversity and similarities of the lived experiences of those interviewed as they navigate various transitions in their life courses. The concepts of 'fateful moments' and 'critical moments' are used to highlight specific events shaping these transitions, focussing in particular on the young people’s lives before and after establishing their businesses. 


\section{Stephen: a life of highs and lows}

Stephen (aged 32) trades in mobile phones at Kwame Nkrumah Circle. On graduating senior high school (SHS) aged 18, he did not secure the grades needful to continue in education, and hence started working in his father's construction company as a labourer. During the three years he occupied this position, his father's health deteriorated and the company folded, bringing about a fundamental change in Stephen's life course. With his limited savings, Stephen rented a parcel of land where he started operating a car washing business. He ran this business for over a year, which he recalled brought some stability into his life. A critical moment then happened, which turned Stephen's life course to one of its lowest ebbs, when the owner of the land announced he needed it for development. Stephen described the period following the takeover of the land as follows:

After losing my business, life went very bad. I was in the house and I had no work to do. I [would] come to town to look for a job, but it doesn't work out and then I go home. It was a very frustrating period in my life.

Stephen stayed at home for close to two years enduring the frustrations and difficulties typical of young people in the city of Accra as they move about in search of jobs (Langevang, 2008; Langevang \& Gough, 2009). On one of his errands in 2004, Stephen met a friend at Kwame Nkrumah Circle who had come there to buy a mobile phone, which turned out to be a critical moment that fundamentally changed his life course. He narrated the event as follows:

One of my sisters had sent me a phone from London which I had on me. It was a Nokia 3310. I sold it to him [friend] for GHC50 (\$23.8) at the time. There was a man across the street holding phones... I used the money to purchase five of the phones from the man. I sold those five phones in a week after which I realised that the phone business was good ... and that was how I started this business.

The above narrative demonstrates the at times haphazard manner in which some young people enter a business sector. With time, Stephen was able to expand his capital base as he reinvested the profit into the business. As well as highs, however, Stephen also experienced lows after entering into the phone business. One such low point occurred in 2007, when the Accra Metropolitan Assembly (AMA) decongested the Circle-Achimota Road, getting rid of traders like Stephen who were selling along the side of the newly reconstructed road. The decongestion 
exercise brought Stephen's business almost to a standstill. He recounted the challenges he faced during this period and how he tried to circumvent them:

The AMA officials evicted all the traders by the roadside. They didn't give us anywhere to sell. All my phones were at home in a bag. I would come here [Kwame Nkrumah Circle] and walk around and if I meet a customer, I would take him somewhere and sell to him.

In 2008, the AMA constructed permanent trading spaces at Kwame Nkrumah Circle, one of which Stephen was able to acquire after paying GHC 500 (\$238.1). He recounted that, “After getting this place, I've become very stable... It is unlike the days when I was selling on the street. Since I moved here, my business has been developing faster than before.”

When asked about some specific gains from his business, Stephen's response reflects the agency he now exercises and some responsibilities he has been able to assume:

Through the business, I was able to acquire a plot of land last year and I've started building my own house. ... I'm also taking care of my mother who is not working, and I pay school fees for my younger siblings.

Despite the fast changing nature of the sector, Stephen sees his future in mobile phones and aspires to expand his business into wholesale activity. This case demonstrates the temporal dimensions of livelihoods replete with highs and lows shaped by different events in the lives of young people as they attempt to move up the social ladder.

Jane: risks, opportunities and choices over the life course Jane (aged 24) trades in airtime at Kaneshie Lorry station. At the age of 10, she lost her father, which she narrated the consequences of as follows:

After my dad died... we were doing whatever we like. When we vacate [from school], I would just come to Accra to sell, not because my mum couldn't help. I felt that my friends were coming so I would just follow them, sell and go back. I never really took my studies seriously. 
While still in SHS, an event that falls squarely under Giddens' (1991) fateful moment, occurred in Jane's life course. Her brother, who was responsible for her school fees, stopped paying as he was away on business and she was not allowed to attend classes. After seeing Jane idling at home, a neighbour gave her money for her school fees. When her brother eventually also gave her money for the fees, the neighbour refused to accept repayment and Jane decided to start a business with the money:

While in school, I had always wanted to engage in something that I don't have to get out of the school to sell. Some of my friends were having phones secretly and when someone was going out, they [would] ask her to buy credit so I thought why don't I bring some to the school to sell?

After selling airtime in the school for a while, and discovering that it was profitable, Jane decided to engage the services of a family relation who could manage the business outside of school. Jane narrated some of the gains from her business as follows:

I feed myself from this business and I get a little to give to my mum at the end of the month... Every year when I go for the Akwanbo festival, I throw a little party for the children. ${ }^{1}$ That's what I do with the little I get from my business and this makes me feel very happy.

The narrative shows how young people do not only engage in business for survival but also for self-fulfilment (Chigunta et al., 2016). Jane further reported that she supports a family relation who is in Junior High School (JHS) with school fees and she is able to rent accommodation for herself.

Jane's case demonstrates the risks as well as opportunities that confront young people in Accra, the choices they make and the consequences of these choices. In their own small ways, young people through their businesses are able to assume responsibilities for themselves, their family and other relations.

\footnotetext{
${ }^{1}$ Akwambo festival is an annual festival celebrated by the chiefs and people of Agona Nyakrom and Agona Swedru in the Central Region of Ghana.
} 


\section{Alex: significance of social capital}

Alex (aged 34) trades in phone accessories at Tema Lorry Station. By his second year of JHS, Alex had lost both of his parents. After completing JHS, he moved to join his brother in Accra, where he started petty trading in household goods before learning tailoring. Alex worked as a tailor for a while but then went back into petty trading as it provided him with a greater income.

Alex has always dreamt of travelling abroad and had been saving to realise this ambition. By 2002, he had been able to save enough money, which he was planning to use to pay a 'connection man' to help him travel to Libya. ${ }^{2}$ However, about the time he was going to pay the money to travel, Alex's girlfriend got pregnant, an incident which comes closest in his life to Gidden's fateful moment. Alex decided to put his travel ambitions aside and used the money to cater for his pregnant girlfriend. Sadly, the child died at the age of three and Alex narrated the situation that confronted him as follows:

That was the saddest day in my life and I will never forget... I loved her dearly and had my hopes in her that at least, if I had not travelled and things didn't go well for me, she would be the evidence of my sacrifice and the legacy I would leave behind.

Two years after the loss of his daughter, a critical moment occurred in Alex's life when he fell ill and had to undergo major surgery following which he stayed at home for about nine months recuperating. After recovering, a friend introduced Alex into the mobile phone accessories business. Alex narrated how this has changed his life as follows: 'This [phone accessories] work has enabled me to regularise my marriage and has given me some form of financial security.'

Alex's future aspiration is to grow the business into a shop or freight container, and to travel outside the country to import mobile phone accessories. His greatest fear is the AMA evicting him from Tema Lorry Station where he plies his trade, highlighting the precariousness of many small businesses (Adam, 2008; Gough et al., 2016).

\footnotetext{
${ }^{2}$ A 'connection man' is an individual who facilitates traveling outside the country for interested persons, mainly through illegal procedures.
} 


\section{Critical events shaping young people's transitions to adulthood}

The biographies of the young people presented above illustrate how their life courses are not unfolding in isolation but rather within wider social spaces. Although engagement in business influences youth transitions, other events within social spaces also play a role. Table 1 presents details of events that shape transitions, as extracted from the narratives of the life trajectory and biographical interviews. The key events have been categorised into five major themes: education, family, social relations and social networks, business, and structural factors. Although the events have been grouped under particular themes, they are clearly interlinked (Gough et al., 2016) and are discussed in more detail below.

\section{Education}

Education related events were significant in their effect on almost all the young people whose life courses were studied, particularly through their ability to pay school fees and either passing or failing exams at JHS or SHS level. The cases of Stephen, Jane, Alex and many others are illustrative of scenarios where failing the final exam at JHS or SHS level serves as a critical event shaping their transitions; this was especially the case prior to 2015, when JHS candidates who failed were not given the opportunity to rewrite. For those who are unable to pass these exams, it becomes a critical event in their lives as they have to re-evaluate their entire life course and the options available to them. In an attempt to move up the social ladder, some young people engage in vocational training activities such as electrics, TV maintenance, tailoring and hairdressing, while others take up self-employment and other income-generation activities (Jones \& Chant, 2009; Langevang \& Gough, 2012). In cases where young people do manage to pass their final exams, they may be able to successfully make the transition to the next level of the educational ladder, though for many this involves running a business alongside their studies in order to pay their fees (Hashim, 2005).

\section{Family}

Key among the family related critical events is parental or familial poverty, which tends to be connected to other life course events. The strongest connection identified in the narratives is the link between poverty and education, where inability to pay school fees is often a crucial factor pushing young people to suspend their education in lieu of self-employment and other remunerative work (Jones \& Chant, 2009). The young people particularly cited instances where either they could not continue in education or had to temporarily stop or drop out entirely from schooling because of the inability of their parents to provide the needed financial support. Apt 
(2007) has similarly observed the financial constraints confronting families, especially in the era of neoliberal policy reforms, which makes it difficult for family members to provide support for each other. The case of Okai supports those of Jane and Alex in illustrating the difficulties parents face in offering financial support to young people in school. Okai is a 28 year old phone repairer who had to stay at home and repeat a class because his parents did not have the money to pay his school fees. He elaborated on this predicament as follows:

When I was in JHS2, I was sent home for school fees. I went to my mother and she said she hasn't got money so I should stay at home. I sat home for months... but when I went back, my friends were already in JHS3 and I had to repeat JHS2. (Okai, 28 years, phone repairer)

Like many young people, the difficulty of affording the cost of school fees and other administrative charges due to family poverty affected Okai and he eventually had to drop out of school in SHS1 to go into self-employment.

\section{Death}

Deaths identified in the narratives with a monumental effect in the life course of young people involve the death of a parent, partner or child. This often creates a void in the lives of young people and in instances where a suitable person is not available to fill this void, a young person's transition is affected the most. In particular, the impact of death on the lives of the young people studied is closely connected with their education. In many instances, young people cited situations where the death of a parent or other close relation has contributed to their inability to further their education. This results in young people dropping out of school and being pushed into income-generating activities (Ampiah \& Adu-Yeboah, 2009; Jones \& Chant, 2009).

In the most severe death-related events, young people have suffered multiple deaths of relatives with serious consequences for their life courses. A typical instance is the case of Foster (aged 18) who was living with his parents and siblings. In 2005 he lost his mother and two years later his junior brother also died. He narrated these shocking events and their affect as follows:

The day my mother died was the saddest day in my life. Also, on $7^{\text {th }}$ March, 2007, I lost my junior brother ... I loved them dearly, but now they are no more. My life has never been the same again. (Foster, 18 years, airtime) 
This highlights the emotional void in the lives of young people due to the loss of close family relations, which typically result in fundamental changes to their life course.

\section{Social Relations and Social Networks}

Critical events identified in the narratives that fall under the category of social relations and social networks include having a relation move abroad, finding a sponsor, meeting old and new friends, and coming into contact with a 'connection man/woman'. The case of Esi (aged 26) is a clear example of this. Esi completed an apprenticeship in hairdressing but could not afford to open her own shop. She got a boyfriend, however, who provided her with a shop and GHC 100 (\$47.6) to start an airtime business. Through this assistance, Esi is currently running an airtime and mobile money business. The case of Stephen presented above exemplifies how events - such as a chance meeting with a friend - can present opportunities. Not all such encounters, however, bring about positive outcomes as Stephen narrated:

\footnotetext{
A friend of mine sold a phone to me. Unknown to me the phone was a stolen phone. I put the phone in the show case and the owner came to buy the phone from me. Later on, the person brought the police. I lost almost all my capital and this could have collapsed my business.
}

This shows the problem of deceit and how social relations can negatively affect young people's businesses. Consequently, whilst social networks generally serve as a repository of resources for young people, this is not always the case.

\section{Structural}

Some of the critical moments which can be classified under structural factors include decongestion exercises conducted by the AMA, road construction works, seizure of goods by state authorities, and depreciation of the Cedi against some international currencies. In some cases, these events are connected to one another, for example, a decongestion exercise paves the way for the construction of a road network which is often accompanied by seizure of goods by the AMA. When this happens, some young people lose their business capital, while others lose their livelihoods entirely. Typical examples are those of Sammy and Stephen whose businesses 
were doing very well but the completion of construction works and subsequent decongestion exercises halted progress in their businesses and life courses.

Turning to another incident of structural nature, most goods traded by young people in the mobile telephony sector are imported, hence Cedi depreciation and consequent hikes in prices affect the capital base of their businesses. When this happens, young people are unable to purchase as much as previously, which affects profitability of their businesses. A typical example is the case of Agya (aged 32) who had to stop traveling to Nigeria to import phones which he sold because of the depreciation of the Cedi to the Naira. Similarly, Fred (aged 22) who trades in phone accessories noted that, “the price of the accessories keep going up and when I go to the importers, I can no longer buy in high quantities like I used to buy.” In both cases, depreciation of the cedi contributed to increasing prices and resultant stagnation in the businesses and the life course. Such structural factors at national and global levels have also been identified as critical constraints elsewhere in sub-Saharan Africa, shaping rural and urban young people's access to self-employment and movement up the social ladder (Hajdu et al., 2013; Gough et al., 2016).

\section{Business influence on youth transitions to adulthood}

Having highlighted some key events that shape young people's transitions within the wider social space, we now draw on the three selected cases and additional biographical and life course interviews to analyse the specific nature of transitions resulting from business engagement in the mobile telephony sector. These can be grouped into financial independence, support for social relations, land access, rental accommodation, and marriage.

\section{Achieving Financial Independence}

Achieving financial independence is identified as a significant milestone in the life of young people (Arnett, 2001; Petrogiannis, 2011). For young people in Accra, however, achieving this status often proves difficult as job opportunities that could facilitate financial independence are simply not available. Many young people are confronted with limited options, resorting to the informal economy for employment (Yankson \& Owusu, 2016), but this is not always a guarantee of financial independence. Alex, for instance, started work as a trader selling insecticides before going into an apprenticeship in tailoring. After working in the tailoring business for two years, he "realised that the profession was not lucrative". He, therefore, went back to petty trading specialising in household goods. Another case is Patricia who traded in yam chips before 
working in a restaurant as a cook. She described her restaurant experience as, “... a very difficult work and the pay was not good so I stopped and went into trading.” Despite working in the informal economy for many years, she was unable to achieve financial independence. For both Alex and Patricia, alongside many other young people, engaging in businesses in the mobile telephony sector accords them with the opportunity to earn relatively more compared with other sectors. With his new-found financial independence from working in the phone accessories trade, Alex noted that, "This business has helped me... as I can say that I now have financial freedom.”

Achieving financial independence through operating in the mobile telephony sector was found to cuts across business types and gender; both females who dominate the airtime trade and their male counterparts who dominate other business types (such as mobile phones and accessories sales, phone repair and technical support services) indicated having managed to achieve financial independence. This is very important in youth transitions to adulthood and for being able to sustain their new found status. This was captured in Stephen's narrative when he stated that, "I see a very bright future for myself, if I'm able to manage this business well. Everything is looking bright for me. With this business my destiny is in my hands.”

Although the young people demonstrated positive aspirations for their businesses, this may not necessarily be enough to sustain their financial independence; failure rates among Ghana business owners in general have been found to be high (Langevang et al. 2015). Structural factors serve as a key threat to young people’s newly found status of financial independence. Gaining and maintaining access to space in the city for business operating purposes is a key challenge (Asiedu \& Agyei-Mensah, 2008), which was well captured in Alex's narrative: "What I fear most is that, one day they [AMA] might drive us out of here [Tema Lorry Station], and if they do, all my plans, hopes and dreams will be shattered.” The majority of young people interviewed see their futures in the mobile telephony sector, despite the fast changing trends and potential threat from the AMA. It is clear, however, that gaining access to business operating space presents one of the greatest challenges facing young entrepreneurs and the informal proletariat generally (Asiedu \& Agyei-Mensah, 2008; Gillespie, 2015).

\section{Support for Social Relations}

Whilst academic literature emphasises the benefits of social relations for young people running businesses, (Clark, 1999; Chant \& Jones, 2005; Hanson, 2005; Langevang, 2008), there is limited discussion of what they, in turn, offer back to their social networks. The young people 
interviewed in this study revealed that working in the mobile telephony sector enabled them to provide support to others. Examples included offering financial assistance to close family relations, such as parents, and paying school fees for younger siblings. The cases of Stephen, Jane and many others depict this type of support. Other instances of support extend beyond the immediate family relations to broader kinship or neighbourhood ties, as captured by Jane:

\author{
Sometimes I would be here and people call from the village to say they need \\ money to pay school fees for their children or buy them uniform, and if I have the \\ money, I give. Had it not been for this business, I wouldn’t have been able to \\ provide this support to the children in my village. (Jane, 24 years, airtime and \\ mobile money)
}

Both young men and women operating within all aspects of the mobile telephony sector were found to be in a position to offer support to their social networks. This ability to support others is one of the key factors in transitioning to being viewed as an adult in a Ghanaian context.

\title{
Ability to Rent Residential Accommodation
}

Rapid population growth has made housing a critical challenge in Ghana's urban space (Acheampong, 2016; ISSER, 2013). Rental values have increased significantly, making it difficult for young people to rent accommodation. Further complicating the situation is the tendency for landlords to charge rent advance payments from at least two years to as high as five years (Arku et al., 2012; Yankson, 2014), an amount that is very difficult for young people to mobilise.

In spite of these difficulties, young people interviewed indicated that they have been able to afford the cost of rental accommodation, attributing this to having a business in the mobile telephony sector. Before establishing their businesses, these same young people reported living with family or friends, or sleeping in public spaces across the city. It is interesting to note how the achievement of paying for rental accommodation cuts across business type and gender. Patience had previously had to rely on her social relations through friendship and hometown ties in order to secure sleeping space with friends. After starting her business in airtime and mobile money, however, she has been able to rent accommodation. As she explained: 
I was initially living with a friend and then I moved to a veranda at a police station. I later went to stay with a friend for about eight months, but for four years now since I started this business, I have been able to rent a room where I stay with my two children. (Patience, 31 years, airtime business)

The importance of managing to rent accommodation was confirmed by Michael (aged 27) who trades in phone accessories at Tema Lorry Station. He told how:

In the past, we were sleeping in people’s kiosks. What made me extremely happy in Accra was when I was able to save money from this business to rent my first room. This has spurred me on that I could do something in my life. (Michael, 27 years, phone accessories)

These cases show how having a business in the mobile telephony sector not only makes it possible for young people to rent accommodation but also has wider implications for their feelings of self-worth and their ability to transition into adulthood.

\section{Ability to Acquire Land}

Despite challenges with land access and home ownership in Accra and other urban spaces in Ghana (Government of Ghana/Ministry of Local Government and Rural Development, 2010), some young people interviewed indicated that their engagement in business in the mobile telephony sector has enabled them to acquire land and some have even started building houses. Stephen is one example; he explained how "I was able to acquire a plot of land at Bortiano last year and I’ve started building my own house.” Another case was Alex who stated that: "It [my business] has helped me purchase a plot of land on which I am building my own house.” Within a Ghanaian socio-cultural setting, acquiring land and building a house is an important symbol of one’s social standing and an important step towards being considered to be an adult.

By acquiring land and starting building, these young people are visibly demonstrating the gains achieved from their businesses. Contrary to the other aspects discussed above, however, the acquisition of land and construction of housing was found to be exclusively a male activity and primarily those involved in phone sales, accessories, repair and technical support businesses. This shows how only a section of young people, males working in the more lucrative businesses in the mobile phone sector, have been able to achieve the status of being land/homeowners. 


\section{Marriage}

Like other African societies, marriage remains one of the key markers of the transition to adulthood for young people in Accra (Langevang, 2008). Whilst marriage places a degree of responsibility on both parties, it has been argued that there has been an increasing feminisation of livelihood responsibilities during the post-adjustment era in Ghana (Chant, 2008; Brydon, 2010). Nevertheless, during the processes leading up to the marital ceremony, men are noted to shoulder much more responsibility in Ghanaian settings as they have to "lay the material foundations for the household” (Langevang 2008, p. 2044). The marital responsibilities placed especially on the man has led to delaying of marriage among young people, although the role education also plays in this regard cannot be discounted. Some of the young people interviewed have been able to marry and subsequently maintain their households as a result of their engagement in business in the mobile telephony sector. The case of Alex exemplifies this point. Prior to starting his accessories business in the mobile telephony sector, Alex was cohabiting with his partner. However, through the relatively higher income flows from his new business he has been able to regularise his marriage. This indicates how for some young people who are cohabiting, business engagement in the mobile telephony sector accords them the opportunity to earn a decent income which is used in regularising marital relationships and maintaining households.

While some young men (and single women) are able to maintain their household through their businesses, as the study cases show, co-habiting/married women's businesses enable them to be supportive of their partners in many instances. Commenting on the benefits of her engagement in the airtime business, for instance, Gladys, an airtime vender stated that, "Through this business, I'm able to offer support to my husband at home. I use the profit from my business to buy food items for the household and I support in the payment of our children's school fees.” Compared to their male counterparts, who are considered to be the household heads, the value of female-run businesses tends to be seen within the context of female support provided for the household more generally (Chant, 2008; Brydon, 2010).

\section{Conclusions}

Using a mapping exercise, life trajectory observations and biographical interviews, this paper has explored the factors shaping young people's transitions to adulthood in urban Accra, especially the impact of their engagement in businesses in the mobile telephony sector. Several key factors were observed to influence these transitions including: education, family-related factors, social 
networks and structural factors, many of which were found to be interrelated. The availability of these factors in the life courses of the young people were identified as contributing to either stagnating or boosting their transitions into adulthood.

With respect to education, passing examinations at the basic or secondary level was identified as playing a critical role in shaping young people's transitions. In Ghana, as in many other African countries, opportunities for young people to continue formal education and/or gain employment are very difficult to come by (Aryeetey et al, 2013; Gough et al., 2016). Compounding this situation is the issue of poverty, which makes it difficult for families to offer the support young people need to further their education. Structural factors, such as the activities of the AMA in enforcing their decongestion exercises, also shape transitions and the life courses of young people. Faced with the lack of availability and at times harsh governance of space, young entrepreneurs in Accra operate their businesses on the street and in other public spaces not designated for business purposes. The challenge of accessing business space makes it difficult for some young people to assume adult responsibilities or move up the social ladder.

Despite the challenges young entrepreneurs face, this paper has shown how many young people operating informal businesses in the mobile telephony sector have been able to achieve financial independence, afford rental accommodation, provide support for family members and establish and sustain households. Consequently, the mobile telephony sector is offering young people the opportunity to carve out a living, facilitate transitions into adulthood, and even enable some to move up the social ladder. By highlighting the agency of this group of young people, and for some their success in achieving the status of adulthood through their hard work and ingenuity, this study thus offers an important counter balance to images of young people in sub-Saharan Africa as being 'stuck’ or in 'waithood' (Sommers, 2012; Honwana, 2014).

These findings highlight how it is imperative for policy makers at all levels in the global South to recognise that by establishing businesses in the informal economy, young people have the possibility of becoming financially independent and making the important transition into adulthood. Not only is there currently limited policy support for young people operating businesses in the informal economy in Ghana, but as this study has shown, many face frequent harassment by the authorities. Changes in how young informal entrepreneurs are perceived and supported is essential if the United Nations Sustainable Development Goal 8, which includes a 
focus on youth employment as an element of the aim of productive employment and decent work for all, is to be achieved.

\section{References}

Acheampong, R. A. (2016). The family housing sector in urban Ghana: exploring the dynamics of tenure arrangements and the nature of family support networks. International Development Planning Review, 38(3), 297-316.

Adams A. V. (2008). "Skills development in the informal sector of Sub-Saharan Africa”. World Bank. Mimeo.

Afutu-Kotey, R. L. (2016). Young entrepreneurs in the mobile telephony sector in Ghana. In K. V. Gough and T. Langevang (Eds.), Young Entrepreneurs in Sub-Saharan Africa. New York and London: Routledge.

Afutu-Kotey, R. L., Gough, K. V., \& Owusu, G. (2017). Young Entrepreneurs in the Mobile Telephony Sector in Ghana: From Necessities to Aspirations. Journal of African Business, DOI: 10.1080/15228916.2017.1339252.

Ampiah, J. G., \& Adu-Yeboah, C. (2009). Mapping the incidence of school dropouts: a case study of communities in Northern Ghana. Comparative Education, 45(2), 219-232.

Ansell, N. (2014). 'Generationing'Development. The European Journal of Development Research, 26(2), 283-291.

Anyidoho, N. A. (2013). Informal Economy Monitoring Study City Level Report: Accra street vendors. WIEGO.

Apt, N. A. (2007). Health and aging in Africa. Global Health and Global Aging, 187.

Arku, G., Luginaah, I., \& Mkandawire, P. (2012). "You Either Pay More Advance Rent or You

Move Out”: Landlords/Ladies' and Tenants’ Dilemmas in the Low-income Housing

Market in Accra, Ghana. Urban Studies, 49(14), 3177-3193.

Arnett, J. J. (2001). Conceptions of the transition to adulthood: Perspectives from adolescence through midlife. Journal of adult development, 8(2), 133-143.

Arnett, J. J. (2007). Emerging adulthood: What is it, and what is it good for? Child development perspectives, 1(2), 68-73.

Arnot, M. Jeffery, R., Casely-Hayford, L. \& Noronha, C. (2012) Schooling and domestic transitions: shifting gender relations and female agency in rural Ghana and India, Comparative Education, 48:2, 181-194

Aryeetey, E., Doh, D., \& Andoh, P. (2013). Choosing an apprenticeship: skills preferences amongst the youth. International Development Planning Review, 35(2), 135-153.

Aryeetey, E., \& Baah-Boateng, W. (2013). Unemployment, underemployment and joblessness in Africa: Can entrepreneurship solve the problem? Paper presented at the International Conference on Entrepreneurship and Employment in the Global South, Copenhagen, June 24-25, 2013.

Asiedu, A. B., \& Agyei-Mensah, S. (2008). Traders on the run: Activities of street vendors in the Accra Metropolitan Area, Ghana. Norsk Geografisk Tidsskrift-Norwegian Journal of Geography, 62(3), 191-202.

Beck, U. (1992). Risk society: Towards a new modernity. London: Sage.

Bell, D. N., \& Blanchflower, D. G. (2011). Young people and the Great Recession. Oxford Review of Economic Policy, 27(2), 241-267. 
Bennell, P. (2000). Improving youth livelihoods in SSA: a review of policies and programmes with particular emphasis on the link between sexual behaviour and economic well-being. Report to the International Development Center (IDRC).

Bennell, P. (2007). Promoting livelihood opportunities for rural youth. Knowledge and Skills for Development Paper. IFAD.

Brydon, L. (2010) 'Post-Adjustment, Post-Mitigation, 'Post-Poverty'? The Feminisation of Family Responsibility in Contemporary Ghana'. In Sylvia Chant (Ed.), The International Handbook of Gender and Poverty: Concepts, Research, Policy (Cheltenham: Edward Elgar), 117-22.

Chant, S. (2008). The "feminisation of poverty" and the "feminisation" of anti-poverty programmes: room for revision?', Journal of Development Studies, 44 (2), 165-97.

Chant, S., \& Jones, G. A. (2005). Youth, gender and livelihoods in West Africa: Perspectives from Ghana and the Gambia. Children's Geographies 3 (2), 185-199.

Chen, M. A. (2012). The informal economy: Definitions, theories and policies. Women in informal economy globalizing and organizing: WIEGO Working Paper, 1.

Chigunta, F., Gough, K. V., \& Langevang, T. (2016). Young entrepreneurs in Lusaka: Overcoming constraints through ingenuity and social entrepreneurship. In K. V. Gough and T. Langevang (Eds.), Young Entrepreneurs in Sub-Saharan Africa. New York and London: Routledge.

Christiansen, C., Utas, M., \& Vigh, H. E. (2006). Introduction: navigating youth, generating adulthood. In: Christiansen, C., Utas, M., Vigh, H.E. (Eds.), Navigating Youth, Generating Adulthood: Social Becoming in an African Context. The Nordic Africa Institute, Uppsala, pp. 9-28

Clark, G. (1999). Negotiating Asante family survival in Kumasi, Ghana. Africa 69 (1), 66-86.

Erikson, E. (1950). Childhood and Society. W.W. Norton \& Co., New York

Furlong, A., \& Cartmel, F. (2007). Young people and social change: new perspectives. Maidenhead.

Giddens, A. (1991). Modernity and self-identity: Self and society in the late modern age. Cambridge: Polity.

Gillespie, T. (2016). Accumulation by urban dispossession: struggles over urban space in Accra, Ghana. Transactions of the Institute of British Geographers, 41(1), 66-77.

Government of Ghana/Ministry of Local Government \&Rural Development. (2010). Draft national urban policy. Accra: MLG\&RD.

Government of Ghana/Ministry of Youth and Sports. (2010). National youth policy of Ghana: Towards an empowered youth, impacting positively on National Development. Accra: GoG/MYS.

Gough, K. V., Chigunta, F., \& Langevang, T. (2016). Expanding the scales and domains of (in) security: Youth employment in urban Zambia. Environment and Planning a, 48(2), 348366.

Gough, K. V., \& Langevang, T. (Eds.). (2016). Young entrepreneurs in sub-Saharan Africa. New York and London: Routledge.

Hajdu, F., Ansell, N., Robson, E., \& van Blerk, L. (2013). Rural young people's opportunities for employment and entrepreneurship in globalised southern Africa: the limitations of targeting policies. International Development Planning Review, 35(2), 155-174.

Hampshire, K., Porter, G., Owusu, S. A., Mariwah, S., Abane, A., Robson, E., \& Milner, J. (2015). Informal m-health: How are young people using mobile phones to bridge healthcare gaps in Sub-Saharan Africa?. Social Science \& Medicine, 142, 90-99.

Hanson, K. (2005). Landscapes of survival and escape: social networking and urban livelihoods in Ghana. Environment and Planning A, 37 (7), 1291-1310.

Hashim, I.M. (2005) Exploring the Linkages between Children's Independent Migration and 
Education: Evidence from Ghana. Working Paper T12. DRC on Migration, Globalisation and Poverty. Brighton: University of Sussex

Helve, H., \& Bynner, J. (2007). Youth and Social Capital. Tufnell Press, London.

Holland, J., Reynolds, T., \& Weller, S. (2007). Transitions, networks and communities: the significance of social capital in the lives of children and young people. Journal of Youth Studies, 10 (1), 97-116.

Honwana, A. (2014). "Waithood": Youth Transitions and Social Change, in: Dick Foeken, Ton Dietz, Leo Haan, and Linda Johnson (eds), Development and Equity: An Interdisciplinary Exploration by Ten Scholars from Africa, Asia and Latin America, Leiden: Brill, 28-40.

Inhelder, B., \& Piaget, J. (1958). The Growth of Logical Thinking from Childhood to Adolescence. Basic Books, New York

ISSER (Institute of Statistical, Social and Economic Research) (2013). Ghana Social Development Outlook 2012. Accra: ISSER.

Jeffrey, C., \& Dyson, J. (2013). Zigzag capitalism: Youth entrepreneurship in the contemporary global South. Geoforum, (49), R1-R3.

Jeffrey, C., \& McDowell, L. (2004). Youth in a comparative perspective: global change, local lives. Youth and Society, 36, 131-42.

Johnson-Hanks, J. (2002). On the limits of life stages in ethnography: toward a theory of vital conjunctures. American Anthropologist, 104, 865-880.

Jones, G. A., \& Chant, S. (2009). Globalising initiatives for gender equality and poverty reduction: Exploring 'failure'with reference to education and work among urban youth in The Gambia and Ghana. Geoforum, 40(2), 184-196.

Kew, J. (2015). Africa's Young Entrepreneurs: Unlocking the Potential for a Brighter Future. Cape Town: Rothko.

Langevang, T. (2008). 'We are managing!' Uncertain paths to respectable adulthoods in Accra, Ghana. Geoforum, 39, 2039-2047.

Langevang, T., \& Gough, K. V. (2012). Diverging pathways: young female employment and entrepreneurship in sub-Saharan Africa. The Geographical Journal, 178(3), 242-252.

Langevang, T., \& Gough, K. V. (2009). Surviving through movement: the mobility of urban youth in Ghana. Social \& Cultural Geography, 10(7), 741-756.

Langevang, T., Gough, K. V., Yankson, P. W., Owusu, G., \& Osei, R. (2015). Bounded entrepreneurial vitality: The mixed embeddedness of female entrepreneurship. Economic Geography, 91(4), 449-473.

Parker, S. C. (2009). The economics of entrepreneurship. Cambridge University Press.

Petrogiannis, K. (2011). Conceptions of the transition to adulthood in a sample of Greek higher education students. International Journal of Psychology and Psychological Therapy, 11(1), 121-137.

Porter, G., Hampshire, K., Abane, A., Munthali, A., Robson, E., Bango, A., \& Milner, J. (2015). Intergenerational relations and the power of the cell phone: Perspectives on young people's phone usage in sub-Saharan Africa. Geoforum, 64, 37-46.

Porter, G., Hampshire, K., Abane, A., Munthali, A., Robson, E., Mashiri, M., \& Tanle, A. (2012). Youth, mobility and mobile phones in Africa: findings from a three-country study. Information Technology for Development, 18(2), 145-162.

Schoof, U. (2006). Stimulating Youth Entrepreneurship: Barriers and incentives to enterprise start-ups by young people (No. 993881573402676). International Labour Organization.

Skelton, T. (2002). Research on youth transitions: some critical interventions. Young people in risk society, 100-116.

Sommers, M. (2010). Urban youth in Africa. Environment and urbanization, 22(2), 317-332.

Sommers, M. (2012). Stuck: Rwandan youth and the struggle for adulthood. University of Georgia Press. 
Thomson, R., Bell, R., Holland, J., Henderson, S., McGrellis, S., \& Sharpe, S. (2002). Critical moments: choice, chance and opportunity in young people's narratives of transition. Sociology, 36 (2), 335-354.

Valentine, G. (2003). Boundary crossings: transitions from childhood to adulthood. Children's Geographies 1(1), 37-52.

Webb, J. W., Bruton, G. D., Tihanyi, L., \& Ireland, R. D. (2013). Research on entrepreneurship in the informal economy: Framing a research agenda. Journal of Business Venturing, 28(5), 598-614.

Worth, N. (2009). Understanding youth transition as 'becoming': identity, time and futurity. Geoforum 40, 1050-1060.

Wyn, J., \& Dwyer, P. (1999). New directive in research on youth in transition. Journal of Youth Studies, 2 (1), 5-21.

Yankson, P. W. K. (2012). 'Rental Housing and Tenancy Dynamics with Particular Focus on Low-income Households in Greater Accra Metropolitan Area', In The Mobile city of Accra: Urban Families, Housing and Residential Practices Eds. Ardayfio-Schandorf, E., Yankson, P.W.K., \& Bertrand, M. CODESRIA.

Yankson, P. W., \& Owusu, G. (2016). Prospects and challenges of youth entrepreneurship in Nima-Maamobi, a low-income neighbourhood of Accra. In K. V. Gough and T. Langevang (Eds.), Young Entrepreneurs in Sub-Saharan Africa. New York and London: Routledge. 